\title{
The Effect of Accountability, Transparency, Religiosity, And Programs Innovation on Muzakki Interest in Paying Zakat At The National Zakat Agency (BAZNAS) Merangin District.
}

\begin{abstract}
Zakat in Islam is a direct command from Allah SWT, as a liaison between the rich and the poor. Where, the rich give some of their wealth in the form of zakat to those who are entitled to receive it. This study aims to determine the effect of accountability, transparency, religiosity, and innovation programs on muzakki's interest in paying zakat. This study uses a purposive sampling technique using $\mathbf{1 0 0}$ samples obtained from the questionnaire data distributed to the people of Merangin Regency. The results in this study found that the variables of accountability, transparency, religiosity, and innovation programs have a positive and significant influence on the interest of muzaki in paying zakat.
\end{abstract}

Asmadi

Index Terms - accountability, transparency, religiusity, program innovation; muzakki interest.

\section{INTRODUCTION}

Indonesia is one of the countries with the largest Muslim population in the world. With a large Muslim majority, Indonesia has the potential to develop instruments of economic equity, especially Indonesian Muslims in the management of zakat, infaq, and shadaqah (ZIS) funds. Based on a study conducted by BAZNAS, the potential for zakat funds in Indonesia reaches Rp. 230 trillion. However, the amount of ZIS fund raising known nationally in 2020 through official OPZ only reached Rp 8 trillion or only 3.2 percent of the potential zakat we have (lokadata.id, 2020). Zakat in Islam is a direct command from Allah SWT, as a liaison between the rich and the poor. Where, rich people give part of their wealth in the form of zakat to those who are entitled to receive zakat (Junjunan et al., 2020).

In this study, researchers from BAZNAS Merangin Regency because Merangin Regency ranks third in Jambi Province, with a total poor population of 32,880 people (BPS KabupatenMerangin, 2020). Meanwhile, according to H. SyafrudinHadi as the head of the Merangin Regency BAZNAS, the potential for ZIS funds in Merangin Regency could reach Rp 50 billion per year. This situation shows that Zakat has a significant impact on poverty alleviation and automatic functioning in the Islamic system. Therefore, as a means of alleviating poverty, zakat can be empowered to realize the welfare of the people.

Asmadi, Fakultas Bisnis dan Ekonomika, Universitas Islam Indonesia, Yogyakarta, Indonesia.
There are several previous studies that raised a similar theme regarding the interest of muzakki such as research conducted by (Rahayu et al., 2019) in this study found that the accountability and transparency of the amil zakat institutions affect the trust of muzakki. In addition, there are other factors that influence the interest of muzakki in paying zakat. Furthermore, research conducted by (Satrio\&Siswantoro, 2016) shows that income, belief, and religious variables have a significant effect on muzakki's interest in paying zakat through the Amil Zakat Institution. In addition, there is also another study conducted by (Ahmad \&Rusdianto, 2018) in his research which found a significant effect of the accountability of the Amil Zakat Institution on public satisfaction. public goals for the Amil Zakat Institution have a significant influence on public trust.

Based on the description above, the researcher is interested in conducting research with the title: "The Effect of Accountability, Transparency, Religiosity and Program Innovation on Muzakki Interest in Paying Zakat at the National Zakat Agency (BAZNAS) Merangin District"

\section{LITERATURE REVIEW}

\section{A. Theory Of Planned Behavior (TPB)}

Theory of Planned Behavior (TPB) is a person's behavioral intention to do something. Behavioral intention is a form of someone's motivation in planning, making decisions, or self-instruction in increasing efforts to do something. In TPB theory, a person's behavioral intentions are determined by three things, namely, attitudes toward behavior, normative support about behavior, and perceived behavioral control. Subjective attitudes and norms can support to motivate behavior, but concrete intentions to do so can only be formed when control over behavior is strong enough. (Ajzen, 2020). A person will have a strong intention to do something if they evaluate the behavior positively, and think that other people will also do it and believe that it is easy to do.

\section{B. Review About Interests}

Interest is the motivation that drives people to do what they want if they have the freedom to choose. Every interest will cause a sense of satisfaction with something someone does. In carrying out its function, the will is closely related to thoughts and feelings. Thoughts tend to move in the rational sector of analysis, whereas feelings that have a subtle/sharp nature are more directed towards needs. While 
the mind functions as a reminder of thoughts and feelings in harmonious coordination, so that the will can be managed as well as possible (Budiyono et al., 2019).

\section{Zakat}

The definition of zakat according to the language comes from the word "zaka" which has the meaning of growing, developing, purifying or cleaning. The definition of zakat growing and developing is that someone spends his wealth to pay zakat, it is hoped that his wealth will continue to grow and develop both in real form in the real world and later in the hereafter. Meanwhile, Zakat in a sacred sense is a form of cleansing oneself, soul and property. Someone who spends his wealth to pay tithe, then that person already has himself and his soul from miserly disease (Syafiq, 2018). Meanwhile, according to figh, zakat is a certain amount that is required by Allah SWT to be issued and handed over to the group of people who are entitled to receive it. Zakat is worship that is both vertical and horizontal. Vertically, namely hablumminallah, namely a person's relationship with Allah SWT as well as a person's signature and piety to Allah SWT and horizontally, namely hablumminannas which means human relations. because zakat has a relationship and benefits that can be felt directly by zakat recipients (mustahik), (Tho'in\&Marimin, 2019).

\section{The Wisdom and Benefits of Zakat}

Zakat is a worship in the field of property that has wisdom and benefits that are so great and noble, both for people who pay zakat (muzakki), for people who receive it (mustahik), for assets that are issued zakat, and for society as a whole (Irawati\&Ratno , 2020). The wisdom and benefits of zakat are as follows: (1) As an embodiment of faith in Allah SWT, being grateful for the blessings, fostering noble character with a high sense of humanity, eliminating stingy, greedy and materialistic nature, fostering peace of life, as well as cleaning and developing assets owned (Junjunan et al., 2020). (2) Zakat can also increase the sense of togetherness in which each other thinks about the fate of fellow human beings. Zakat functions to help each other and foster those who are poor and needy to lead a prosperous life (Junjunan et al., 2020). (3) Zakat gives wisdom to humans that humans as social beings cannot live only by thinking about their own interests. Humans need each other, therefore zakat can create a sense of empathy for fellow human beings. Zakat can also eliminate envy and envy, zakat can also erase the boundary between the poor and the rich (Purbasari et al., 2020).

\section{- The Effect of Accountability on Muzakki's Interest in} Paying Zakat

Accountability is a form of accountability between the recipient of the mandate and the giver of the mandate. In the view of Islam accountability is a form of responsibility of a Allah SWT as the creator. because in Islam anything that has been entrusted (mandated) to humans must be accounted for everything before Allah.

Research (Rahayu et al., 2019) states that the accountability variable has a significant effect on the level of trust in muzakki. These results support and strengthen the results of the first hypothesis which says that accountability has an effect on the level of muzakki. Therefore, with the best possible accountability from BAZNAS, it will increase the sense of muzakki to pay their zakat at BAZNAS. Based on the above review, the hypotheses to be tested in this study are:

H1: Accountability has a positive effect on Muzakki's interest in paying zakat at BAZNAS, Merangin Regency

\section{- The Effect of Transparency on Muzakki's Interest in Paying Zakat}

Transparency is the openness of an agency in providing information related to resource activities and financial reporting issues. Transparency is a process of openly submitting reports to interested parties related to the operation or management by conveying all aspects as the basis for decision making and the process of implementing activities (Kumalasari\&Riharjo, 2016).

In the study (Kabib et al., 2021) it was found that the transparency variable simultaneously affects the interest of muzakki in paying zakat at BAZNAS Sragen Regency. However, partially, the transparency variable has no significant effect on the interest of muzakki in paying zakat in BAZNAS, Sragen Regency. Furthermore, in another study conducted by (Pangestu\&Jayanto, 2017) stated that the transparency variable had a significant effect on the motivation of muzakki to pay zakat at the Amil Zakat Institute in Semarang City. Based on the above review, the hypotheses to be tested in this study are:

H2: Transparency has a positive effect on Muzakki's interest in paying zakat at BAZNAS, Merangin Regency.

\section{- The Effect of Religiosity on Muzakki's Interest in Paying Zakat}

Religiosity can be interpreted as a person's devotion to the religion he believes in, believing in the greatness of God as the creator of the universe, and a sense of submission and obedience to all of God's commands. For a Muslim, religiosity can be measured by the extent of knowledge, belief, practice of worship, and appreciation of the religion of Islam.

In the study (Mirawati et al., 2019) it was stated that the religiosity variable had a significant effect on the interest of muzakki to pay zakat at BAZNAS in Bogor city. Furthermore, research (Wibawa\&Ratnasari, 2018) states that religiosity consists of faith, Islamic knowledge, worship intensity, and religious experience which will have an impact on the level of IstiqomahMuzakki in Surabaya. Based on the description above, the hypotheses to be tested in this study are:

H3: Religiosity has a positive effect on Muzakki's interest in paying zakat at BAZNAS, Merangin Regency.

\section{- The Effect of Innovation on Muzakki's Interest in Paying Zakat}

Research conducted by (Budiman, 2017) Bapelurzam innovations are categorized into two, namely: (a) inventions, (inventions) are creations that have never been done. This form of innovation is related to the determination of the object of zakat which includes all assets, both productive goods and goods for personal use. (b) Synthesis is a combination of existing concepts into new formulations. 
This type of innovation is in the form of productive use of zakat in the form of revolving funds in the form of qardhulhasan. The implication of innovation and participation in zakat management carried out by Bapelurzam has been that the function of zakat is not only limited to the charitable aspect, but is able to empower the economy of the poor. More than that, productivity also changes someone who was previously a mustahik and then becomes a muzakki. In this case, the aspect of community empowerment is the key word for Bapelurzam's zakat management. Based on the description above, the hypotheses to be tested in this study are:

H4: Program Innovations Have a Positive Effect on Muzakki's Interest in Paying Zakat at BAZNAS, Merangin Regency.

\section{METHODOLOGY}

\section{A. Population and Sample}

The population in this study is Muzakki who lives in the Merangin Regency area. The sample in this study was based on purposive sampling. The sample in this study is the people who live and pay their zakat in the Merangin Regency area. The number of samples to be taken is 100 respondents who live in the Merangin Regency area.

\section{B. Data types and sources}

Sources of data relevant to this research are primary data sources. The primary data in this study were obtained from the results of questionnaires distributed to the community or muzakki who live in the Merangin Regency area.

\section{Research Approach}

This research is a type of quantitative research with a survey approach and data collection using a questionnaire. The measurement method in this study uses a Likert scale.
The Likert scale is used to measure the variables to be described with measurable indicators. These indicators are used as the basis for making instrument items in the form of questions or statements that need to be answered by respondents.

\section{Data analysis technique}

Data analysis in this study used multiple linear regression with the help of SPSS 25 software. In this study, several data analysis techniques were used. Data analysis in this study includes, muzakki profile analysis, descriptive analysis of respondents' assessment of research variables, research instrument testing, classical assumption test, multiple linear regression analysis and ends with a discussion of research results.

\section{RESULT AND DISCUSSION}

\section{A. Classic assumption test}

The classical assumption test was carried out to ensure that in the research the data produced had a normal distribution and there was no multicollinearity and heteroscedasticity.

\section{B. Normality test}

The normality test aims to test whether the two regression models of the dependent variable and the independent variable are both normally distributed. A good regression model is a model that is normally distributed. In principle, normality can be detected by looking at the distribution of the data on the diagonal axis of the graph or looking at the histogram of the residuals. To test the normality of the data, one of the methods used is to look at the results of the Kolmogorov Smirnov test. If the probability $>0.05$ then the research data is normally distributed. The following are the results of the normality test shown in table 1 .

Table1Normality Test Results with Kolmogorov Smirno

\begin{tabular}{|l|c|c|c|}
\hline Variable & Kolmogorov-Smirnov Z & Asymp. Sig. (2-tailed) & Description \\
\hline Unstandardized Residual & 0.566 & 0.906 & Normal \\
\hline
\end{tabular}

Source: Secondary Data processed 2021

Based on the Kolmogorov Smirnov test above, it can be seen that the Kolmogorov Smirnov value is 0.566 and the probability value is 0.906 , which means it is greater than 0.05 . So it can be concluded that this regression model is normally distributed.

\section{Multicollinearity Test}

Multicollinearity test is used to test whether the regression model has a correlation between one independent variable and the other independent variables. If there is no correlation between independent variables, then the regression model is said to be good. If the Variance Inflation Factor (VIF) shows the number <10, then it is declared free of multicollinearity (Sujarweni, 2016). The results of the multicollinearity test can be shown in table 2: 
The Effect of Accountability, Transparency, Religiosity, And Programs Innovation on Muzakki Interest in Paying Zakat At The National Zakat Agency (BAZNAS) Merangin District.

Table 2, Multicollinearity Test Results

\begin{tabular}{|c|c|c|c|}
\hline Independent Variable & Tolerance & VIF & Description \\
\hline Accountability & 0.450 & 2.222 & There is no multicollinearity \\
\hline Transparency & 0.418 & 2.391 & There is no multicollinearity \\
\hline Religiosity & 0.425 & 2.354 & There is no multicollinearity \\
\hline Innovation Program & 0.564 & 1.774 & There is no multicollinearity \\
\hline
\end{tabular}

Source: Secondary Data processed 2021

The results of the multicollinearity test above can be seen that all independent variables have a tolerance value greater than 0.1 and a VIF value less than 10 , so it can be concluded that there are no symptoms of multicollinearity in the regression model.

\section{Heteroscedasticity Test}

The heteroscedasticity test aims to perform a regression between the independent variables and the absolute residual variable. If the value of $\mathrm{sig}>0.05$, it means that the relevant variable is declared free from heteroscedasticity. If there is heteroscedasticity, it can be said that the variance of the variables in the model is not the same (constant). The following are the results of the heteroscedasticity test shown in table 3.

Tebel 3, Heteroscedasticity Test Results

\begin{tabular}{|c|c|c|c|c|c|}
\hline \multirow{2}{*}{ Model } & \multicolumn{2}{|c|}{ Unstandardized Coefficients } & $\begin{array}{c}\text { Standardized } \\
\text { Coefficient }\end{array}$ & \multirow{2}{*}{ Sig } \\
\cline { 2 - 5 } & $\mathrm{B}$ & Std. Error & Beta & & \\
\hline $1 \quad$ (Constant) & .652 & .180 & & 3.630 & .000 \\
Accountability & -.078 & .049 & -.238 & -1.610 & .111 \\
Transparency & -.072 & .067 & -.164 & .1 .073 & .286 \\
Religiosity & .055 & .055 & .151 & .995 & .322 \\
Innovation Program & .008 & .046 & .024 & .853 & \\
\hline
\end{tabular}

Source: Secondary Data processed 2021

Based on the results of the heteroscedasticity test, the significance of accountability (X1) is 0.111 , transparency (X2) is 0.286 , religiosity $(\mathrm{X} 3)$ is 0.322 , and innovation $(\mathrm{X} 4)$ is 0.855 which is greater than 0.05 . So that the variables in this study did not occur heteroscedasticity because the significance level was greater than 0.05 .

\section{E. Coefficient Determination}

The coefficient of determination is used to be able to see the magnitude of the contribution between the independent variable and the dependent variable. The value of R2 lies between 0 to 1 ( 0 R2 1). The purpose of calculating the coefficient of determination is to see the effect of the independent variable on the dependent variable. From the results of data analysis obtained the following results:

Table 4, coefficient of determination

\begin{tabular}{|c|c|c|c|c|}
\hline Model & R & R Square & Adjusted R Square & Std. Error of The Estimate \\
\hline 1 & $.801^{\mathrm{a}}$ & .642 & .627 & .41450 \\
\hline
\end{tabular}

\section{Source: Secondary Data processed 2021}

To determine the size of the influence of the independent variables on the dependent variable, it can be seen from the size of the adjusted $\mathrm{R}$ square. The results of the coefficient of determination can be shown in table 12 , it can be seen the magnitude of the coefficient of determination (Adj.R Square) $=0.627$ which indicates that the variables of Accountability (X1), Transparency (X2), Religiosity (X3) and Innovation Program (X4) together have influencing the variable of muzakki's interest in paying zakat by $62.7 \%$, the remaining $37.3 \%$ is influenced by other independent variables that are not included in the model.

F. Hypothesis testing

1. Multiple Linear Regression Analysis 
Multiple linear regression analysis to examine the effect of the variables Accountability (X1), Transparency (X2), Religiosity (X3) and Innovation Program (X4) on the interest of muzakki in paying zakat is shown in table 5 below:

Table 5, Multiple Linear Regression Test Results

\begin{tabular}{|c|c|c|c|}
\hline \multirow[b]{2}{*}{ Model } & \multicolumn{2}{|c|}{ Unstandardized Coefficients } & \multirow[b]{2}{*}{ Sig } \\
\hline & $\mathrm{B}$ & Std Error & \\
\hline 1 (Constant) & .232 & .299 & .441 \\
\hline Accountability & .214 & .081 & .010 \\
\hline Transparency & .367 & .112 & .001 \\
\hline Religiosity & .202 & .092 & .030 \\
\hline Innovation Program & .169 & .076 & .028 \\
\hline
\end{tabular}

Source: Secondary Data processed 2021

In this study, the following multiple linear regression equation model was used: $Y=a+b_{1} X_{1}+b_{2} X_{2}+b_{3} X_{3}+b_{4} X_{4}$

By paying attention to the regression model and the results of multiple linear regression, the equations of factors that influence the interest of muzakki in paying zakat are obtained as follows:

$$
Y=0.232+0,214 X_{1}+0,367 X_{2}+0,202 X_{3}+0,169 X_{4}
$$

Based on various parameters in the regression equation regarding the factors that influence muzakki's interest in paying zakat, the following interpretation can be given: Constant (coefficient), Constant of 0.232 indicates that if the independent variables (accountability, transparency, religiosity, and innovation) it is assumed that there is no change (constant) then the value (Y) of muzakki's interest in paying zakat will be 0.232 .

Accountability Coefficient, Accountability (X1) has a positive influence on muzakki's interest in paying zakat, with a regression coefficient of 0.214 . With this positive influence, it means that there is a unidirectional relationship between accountability and muzakki's interest in paying zakat. The better accountability results in the interest of muzakki in paying zakat will also increase, as well as poor accountability, the interest of muzakki in paying zakat will decrease.

Transparency Coefficient, Transparency (X2) has a positive influence on muzakki's interest in paying zakat, with a regression coefficient of 0.367 . With this positive influence, it means that there is a unidirectional relationship between transparency and muzakki's interest in paying zakat. The transparency factor increases, the interest of muzakki in paying zakat will also increase, as well as the decreasing transparency factor, the interest of muzakki in paying zakat will also decrease.

The coefficient of religiosity, religiosity (X3) has a positive influence on muzakki's interest in paying zakat, with a regression coefficient of 0.335 . With this positive influence, it means that between religiosity and muzakki's interest in paying zakat shows a unidirectional relationship. The better the religiosity, the muzakki's interest in paying zakat will also increase, as well as the declining religiosity, the muzakki's interest in paying zakat will also decrease.

The coefficient of Innovation, Innovation (X4) has a positive influence on the interest of muzakki in paying zakat, with a regression coefficient of 0.169 . With this positive influence, it means that the innovation program and muzakki's interest in paying zakat shows a unidirectional relationship. The innovation program is getting better resulting in the interest of muzakki in paying zakat will also increase, as well as the innovation program which is decreasing, the interest of muzakki in paying zakat will also decrease.

\section{T Test (Partial)}

Based on Table 6, it can be seen that the sig $t$ value for each independent variable is known and can be used as a basis for decision making by comparing it with a significance level of 0.05 . The following are the results of the partial $\mathrm{t}$ test shown in table 6 . 
Table 6, Test Results (t Partial)

\begin{tabular}{|c|l|c|c|c|}
\hline No & \multicolumn{1}{|c|}{ Hypothesis } & T test & p-value & description \\
\hline 1 & $\begin{array}{l}\text { H1: Accountability has a positive effect on } \\
\text { Muzakki's interest in paying zakat at BAZNAS, } \\
\text { Merangin Regency }\end{array}$ & 2.642 & 0.010 & H1 accepted \\
\hline 2 & $\begin{array}{l}\text { H2: Transparency has a positive effect on Muzakki's } \\
\text { interest in paying zakat at BAZNAS, Merangin } \\
\text { Regency }\end{array}$ & 3.270 & 0.001 & H2 accepted \\
\hline 3 & $\begin{array}{l}\text { H3: Religiosity has a positive effect on Muzakki's } \\
\text { interest in paying zakat at BAZNAS, Merangin } \\
\text { Regency }\end{array}$ & 2.198 & 0.030 & H3 accepted \\
\hline 4 & $\begin{array}{l}\text { H4: Program Innovations Have a Positive Effect on } \\
\text { Muzakki's Interest in Paying Zakat at BAZNAS, } \\
\text { Merangin Regency }\end{array}$ & 2.227 & 0.028 & \\
\hline
\end{tabular}

Source: Research Data, 2021

\section{- T-Calculation Test on Accountability Variables}

The results of the significance test show that the Accountability variable (X1) has a positive t-count value of 2.642 and a p-value / sig t of 0.010 , which means $\mathrm{p}$ value $<0.05$. This value can prove that Ho is rejected, which means that there is a positive and significant effect of the accountability variable on muzakki's interest in paying zakat. Thus, the first hypothesis which states that "Accountability has a Positive Effect on Muzakki's Interest in Paying Zakat at BAZNAS, Merangin Regency", is supported.

\section{- T-Calculation Test on Transparency Variables}

The results of the significance test show that the Transparency variable (X2) has a positive t value of 3.270 and a $\mathrm{p}$-value/ sig $\mathrm{t}$ of a sig $\mathrm{t}$ value of 0.001 which means $\mathrm{p}$ value $<0.05$. This value can prove that Ho is rejected, which means that there is a significant effect of the transparency variable on muzakki's interest in paying zakat. Thus the second hypothesis which states that "H2: Transparency has a Positive Effect on Muzakki's Interest in Paying Zakat at BAZNAS in Merangin Regency", is supported.

\section{- T-Count Test on Religiosity Variables}

The results of the significance test show that the religiosity variable (X3) has a positive t value of 3.270 and a $\mathrm{p}$-value / sig t of a sig t value of 0.030 which means $\mathrm{p}$ value $<0.05$. This value can prove that Ho is rejected, which means that there is a significant influence of the religiosity variable on muzakki's interest in paying zakat. Thus the third hypothesis which states that "|H3: Religiosity has a Positive Effect on Muzakki's Interest in Paying Zakat at BAZNAS Merangin Regency", is supported.

\section{- T-Calculation Test on Program Innovation Variables}

The results of the significance test show that the program innovation variable $(\mathrm{X} 4)$ has a positive t value of 2.227 and a $\mathrm{p}$-value / sig t of a sig $\mathrm{t}$ value of 0.028 , which means $\mathrm{p}$ value $<0.05$. This value can prove that Ho is rejected, which means that there is a significant effect of program innovation on muzakki's interest in paying zakat. Thus, the fourth hypothesis which states that "H4: Program Innovation Has a Positive Effect on Muzakki's Interest in Paying Zakat at BAZNAS, Merangin Regency", is supported.

\section{The Effect of Accountability on Muzakki's Interest in Paying Zakat}

Based on the results of the study indicate that accountability has a positive and significant effect on the interest of muzakki in paying zakat, it can be interpreted that the better accountability will affect the interest of muzakki in paying zakat. On the other hand, if accountability is bad, it will reduce muzakki's interest in paying zakat.

Accountability is an obligation of the trust holder to provide accountability, present information, report all activities and activities that are their responsibility to the trustee who has the right of authority to ask for accountability (Salmawati\&Fitri, 2018). In the view of Islam accountability is a form of accountability of a human being to Allah SWT as the creator, because in Islam anything that has been entrusted (mandated) to humans must be held accountable for everything before Allah. Activities that are effective and efficient and carried out in accordance with the rules can increase the trust of muzakki to pay institutionally (Kamaruddin\&Auzair, 2020). The results of this study are in accordance with research conducted by (Rahayu et al., 2019) which states that the accountability variable has a significant effect on the level of trust in muzakki. Furthermore, the research (Kabib et al., 2021) also states that the accountability variable affects the interest of muzakki in paying zakat.

The Effect of Transparency on Muzakki's Interest in Paying Zakat 
The results show that transparency has a positive and significant effect on muzakki's interest in paying zakat, meaning that the better the level of transparency, the higher the interest of muzakki in paying zakat. On the other hand, if transparency is poor, it will reduce muzakki's interest in paying zakat. Transparency in the implementation of public services must be open, and easily accessible to all parties who need it adequately and easily understood. Thus, the availability of adequate information will affect individual interests.

Transparency is submitting reports to all parties openly, related to the operation of a management by including all elements as the basis for decision making and the process of implementing activities. Building transparency in zakat management will create a good control system between two parties, namely institutions and stakeholders, because it does not only involve internal organizations (zakat institutions) but also external parties, namely muzakki or the wider community (Junjunan et al., 2020).

The results of this study support research (Pangestu\&Jayanto, 2017) which states that the transparency variable has a significant effect on the motivation of muzakki to pay zakat at the Amil Zakat Institute in Semarang City. The results are also in accordance with research (Mutmainah, 2015) which states that the independent variable of transparency increases the interest of muzakki to pay zakat.

\section{The Effect of Religiosity on Muzakki's Interest in Paying Zakat}

Based on the research results, the religiosity variable has a positive and significant effect on the interest of the muzakki to pay zakat, meaning that the higher the level of religiosity of the muzakki, the higher the interest of the muzakki to pay their zakat. Religiosity can be interpreted as a person's devotion to the religion he believes in, believing in the greatness of God as the creator of the universe, and a sense of submission and obedience to all of God's commands. For a Muslim, religiosity can be measured by the extent of knowledge, belief, practice of worship, and appreciation of the religion of Islam. A person's commitment in carrying out his religious orders is what is referred to as religiosity. The level of religiosity that can be used to overcome social problems. One of them, in Islamic teachings, zakat is an alternative that can be used to overcome poverty and distribute social welfare. Someone who has high religiosity tends to obey the command of zakat more (Bin-Nashwan et al., 2019).

The results of the study support the opinion expressed by (Mirawati et al., 2019) which states that the religiosity variable has a significant effect on the interest of muzakki to pay zakat at BAZNAS in Bogor city. Furthermore, research (Mirawati et al., 2019) states that religiosity consists of faith, Islamic knowledge, intensity of worship, and religious experience which will have an impact on the level of IstiqomahMuzakki. In the study (Satrio\&Siswantoro, 2016) found that religiosity had a significant effect on the interest of muzakki to pay zakat through the Amil Zakat Institution.

\section{The Effect of Program Innovation on Muzakki's Interest in Paying Zakat}

The results show that program innovation has a positive and significant effect on muzakki's interest in paying zakat, meaning that the better the program innovation is carried out, it will increase muzakki's interest in paying zakat, and vice versa with poor innovation programs it will reduce muzakki's interest in paying zakat.

Innovation is a process of combining activities that will produce a new product or service that can be marketed. Innovation is success both socially and economically because of the application of new ways or new combinations in converting inputs into outputs in such a way as to produce a significant change between the value of benefits and prices according to consumer or user perceptions (Setiawan, 2019).

\section{CONCLUSION}

The purpose of this study was to determine whether accountability, transparency, religiosity, and innovation programs have an influence on muzakki's interest in paying zakat. After seeing the results of the research that has been discussed, the following conclusions can be drawn:

1. Accountability has a significant positive effect on muzakki's interest in paying zakat. This means that the better the accountability, the muzakki's interest in paying zakat also increases.

2. Transparency has a significant positive effect on muzakki's interest in paying zakat. This means that the better the transparency, the muzakki's interest in paying zakat also increases.

3. Religiosity has a significant positive effect on muzakki's interest in paying zakat. the better the religiosity, the muzakki's interest in paying zakat also increases.

4. The innovation program has a significant positive effect on the interest of muzakki in paying zakat. good improvement program innovation, the interest of muzakki in the meaning of paying zakat is also increasing.

\section{Research limitations}

This research is inseparable from limitations that require improvement and development in subsequent research, the limitations in this study are:

1. The research sample only revealed 100 respondents and the location was only conducted in Merangin Regency, Jambi Province, so the results cannot be generalized to a wider scope of research.

2. Limited references regarding innovation program variables that have not been found so it is difficult to see comparisons of research results.

\section{Suggestion}

Based on the results of the conclusions can be given suggestions that are useful for:

1. Further research can be carried out by considering other potential variables that have not been used in this study, for example the variable influence of income or knowledge of muzakki. 
2. Future researchers are expected to be able to use additional methods other than questionnaires in order to obtain more objective results, for example using interviews and or other methods.

3. Future researchers are expected to be more active in data collection by waiting for the data collection process so that the questionnaire is completely filled out by the intended person and if there are questions from respondents, they can be answered immediately.

4. Further researchers are expected to add samples from outside Merangin Regency.

\section{REFERENCES}

[1] Ahmad, Z. A., \& Rusdianto. (2018). The Analysis of Amil Zakat Institution/Lembaga Amil Zakat (LAZ) Accountability toward Public Satisfaction and Trust. Muqtasid: Jurnal Ekonomi Dan Perbankan Syariah, 9(2), 109. https://doi.org/10.18326/muqtasid.v9i2.109-119.

[2] Ajzen, I. (2020). The theory of planned behavior: Frequently Asked Questions. Human Behavior And Emerging Technologies, 2(4), 314324. https://doi.org/10.1002/hbe2.195.

[3] Atabik, A. (2015). Manajemen pengelolaan zakat yang efektif di era kontemporer. 2(1), 41-62.

[4] Bin-Nashwan, S. A., Abdul-Jabbar, H., \& Aziz, S. A. (2019). Do Enforcement, Religiosity And Peer Influence Zakah Compliance Behavior? International Journal Of Financial Research, 10(6), 42-53. Https://Doi.Org/10.5430/Ijfr.V10n6p42.

[5] BPS Kabupaten Merangin. (2020). https://meranginkab.bps.go.id/.

[6] Budiyono, Putri, S. A. R., \& Tho'in, M. (2019). Effect of Income Rate, Education, Religiosity to Muzakki Interest to Pay Zakat; Case Study of National Amil Zakat Board Central Java. 101(Iconies 2018), 406-409. https://doi.org/10.2991/iconies-18.2019.78

[7] Hildawati, Antong, \& Ramadhan, A. (2021). Pengaruh Pemahaman, Trust , Dan Transparansi Lembaga Zakat Terhadap Minat Masyarakat Membayar Zakat Pada BAZNAS Kabupaten Luwu. 21(2), 1-15.

[8] Junjunan, M. I., Asegaf, M. M., \& Takwil, M. (2020). Pengaruh Transparansi, Akuntabilitas, dan IGCG terhadap Tingkat Kepercayaan Muzakki di Lembaga Amil Zakat Dompet Amanah Umat. Akuntansi : Jurnal Akuntansi Integratif, $\quad 6(2), \quad 112-125$. https://doi.org/10.29080/jai.v6i2.289.

[9] Kabib, N., Umar, A. U. A. Al, Fitriani, A., Lorenza, L., \& Mustofa, muammar T. L. (2021). Pengaruh Akuntabilitas dan Transparansi Terhadap Minat Muzakki Membayar Zakat di BAZNAS Sragen. Jurnal Ilmiah Ekonomi Islam, 7(1), 341. https://doi.org/10.29040/jiei.v7i1.2156.

[10] Kamaruddin, M. I. H., \& Auzair, S. M. (2020). Measuring 'Islamic accountability' in Islamic social enterprise (ISE). International Journal of Islamic and Middle Eastern Finance and Management, 13(2), 303321. https://doi.org/10.1108/IMEFM-04-2018-0134.

[11] Kharisma, A. S., \& Putri, N. K. (2020). Teori Of Planned Behavior Terhadap Intensi Untuk Berinfak Dan Sedekah Melalui Financial. Perada: Jurnal Studi Islam Kawasan Melayu, 3(2), 145-154.

[12] Mirawati, N., Tanjung, H., \& Arif, S. (2019). View Metadata, Citation And Similar Papers At Core.Ac.Uk. 19, 274-282.

[13] Mutmainah, L. (2015). The Influence of Accountability, Transparency, and Responsibility of Zakat Institution on Intention to Pay Zaka. Metrologia, http://publicacoes.cardiol.br/portal/ijcs/portugues/2018/v3103/pdf/3103 009.pdf\%0Ahttp://www.scielo.org.co/scielo.php?script=sci_arttext\&pi $\mathrm{d}=\mathrm{S} 0121$ -

75772018000200067\&lng=en\&tlng=en\&SID=5BQIj3a2MLaWUV4Oi zE\%0Ahttp://scielo.iec.pa.gov.br/scielo.php?script=sci_

[14]Nizar, N. S., \& Falikhatun. (2020). Comparison of Accounting for Zakat Implementation in Indonesia and Malaysia. 1(02).

[15]Osman, A. F., Mohammed, M. O., \& Fadzil, A. (2016). Factor Influencing Cash Waqf Giving Behavior : a Revised Theory of Planned Behavior. Journal of Global Business and Social Entrepreneurship (GBSE), 1(2), 12-25.

[16]Pangestu, I., \& Jayanto, P. Y. (2017). Analysis in Factors Affecting Muzakki Motivation to Pay Zakat in Semarang City. Accounting
Analysis Journal, 6(1), 90-99. Universitas Negeri Semarang. $\mathrm{http}: / / \mathrm{www}$.internationalresearchjournaloffinanceandeconomics.com

[17]Purbasari, L. T., Sukmana, R., \& Ratnasari, R. T. (2020). Efektivitas Zakat, Infaq Dan Shodaqoh Dalam Mengentaskan Kemiskinan Di Indonesia: Menggunakan Teknik Basic Needs Deficiency Index. Jurnal Ekonomi Syariah Teori Dan Terapan, 7(2), 222 https://doi.org/10.20473/vol7iss20202pp222-233.

[18]Rahayu, S. B., Widodo, S., \& Binawati, E. (2019). Pengaruh Akuntabilitas Dan Transparansi Lembaga Zakat Terhadap Tingkat Kepercayaan Muzakki (Studi Kasus Pada Lembaga Amil Zakat Masjid Jogokariyan Yogyakarta). Journal Of Business And Information Systems (E-ISSN: $\quad 2685-2543), \quad 1(2), \quad 103-114$ Https://Doi.Org/10.36067/Jbis.V1i2.26.

[19]Roziq, A., Sulistiyo, A. B., Shulthoni, M., \& Anugerah, E. G. (2021) An Escalation Model of Muzakki's Trust and Loyalty towards Payment of Zakat at BAZNAS Indonesia. Journal of Asian Finance, Economics and Business, 8(3), 551-559. https://doi.org/10.13106/jafeb.2021.vol8.no3.0551.

[20] Satrio, E., \& Siswantoro, D. (2016). Analisis Faktor Pendapatan, Kepercayaan Dan Religiusitas Dalam Mempengaruhi Minat Muzakki Untuk Membayar Zakat Penghasilan Melalui Lembaga Amil Zakat. Simposium Nasional Akuntansi XIX, 1(4), 308-315.

[21] Sawmar, A. A., \& Mohammed, M. O. (2021). Enhancing Zakat Compliance Through Good Governance: A Conceptual Framework ISRA International Journal of Islamic Finance, ahead-of-p (ahead-ofprint), 136-154. https://doi.org/10.1108/ijif-10-2018-0116.

[22] Setiawan, I. (2019). Inovasi Penyaluran Dana Zakat Pada Program Pemberdayaan Di Lembaga Amil Zakat. 21(1).

[23] Syafiq, A. (2018). Peningkatan Kesadaran Masyarakat dalam Menunaikan Zakar, Infaq, Sedekah dan Wakaf. Ziswaf, Jurnal Zakat Dan Wakaf, 5(2), 24.

[24] Tho'in, M., \& Marimin, A. (2019). Faktor-faktor yang Mempengaruhi Minat Muzakki Dalam Membayar Zakat. Sekolah Tinggi Ilmu Ekonomi AAS Surakarta, September, 89-93. 